\title{
MENINGKATKAN KEMAMPUAN GURU DALAM MENERAPKAN PEMBELAJARAN KONTEKSTUAL MELALUI FOCUS GROUP DISCUSSION (FGD) DI SMK NEGERI 1 SIRANDORUNG TAHUN PELAJARAN 2017/2018
}

\author{
Syafaruddin Siregar
}

Kepala SMK Negeri 1 Sirandorung

\begin{abstract}
Abstrak
Tujuan penelitian ini adalah meningkatkan kemampuan guru dalam menerapkan pembelajaran kontekstual melalui Focus Group Discussion (FGD). Penelitian tindakan sekolah ini dilakukan sebanyak 2 siklus yang masing-masing siklus terdiri dari empat kegiatan, yaitu perencanaan (planning), pelaksanaan (acting), pengamatan (observing), dan refleksi (reflecting). Penelitian Tindakan ini dilaksanakan pada 6 orang guru SMK Negeri 1 Sirandorung pada semester genap tahun pelajaran 2017/2018. Metode analisis data dengan menggunakan teknik analisis statistik deskriptif penskoran yang kemudian dipersentase. Hasil dari penelitian ini adalah bahwa melalui kegiatan Focus Group Discussion (FGD) mampu meningkatkan kemampuan dan ketrampilan guru dalam menerapkan pembelajaran kontekstual, hal dapat dilihat dari hasil penelitian terdapat peningkatan pada siklus I yang berkemampuan baik 14,26\%, cukup 52,38 $\%$, kurang 33,26 \%, dan pada siklus II yang berkemampuan sangat baik 52,38 \%, baik 45,23 \%, cukup 2,39\%.
\end{abstract}

Kata Kunci: Kemampuan Guru, Pembelajaran Kontekstual, Focus Group Discussion

\section{Pendahuluan}

Guru sebagai agen pembelajaran harus memiliki kemampuan menerapkan berbagai model pembelajaran. Yang dimaksud dengan kemampuan di sini pada hakikatnya sama dengan kompetensi. Pengertian kompetensi adalah sebagai pengetahuan, keterampilan, dan kemampuan yang dikuasai oleh seseorang yang telah menjadi bagian dari dirinya, sehingga ia dapat melakukan perilaku- perilaku kognitif, afektif, dan psikomotorik dengan sebaikbaiknya.

Pembelajaran yang berorientasi pada penguasaan materi terbukti berhasil dalam kompetisi “mengingat” jangka pendek tetapi gagal dalam membekali anak memecahkan persoalan dalam kehidupan jangka panjang. Pendekatan kontekstual (Contextual Teaching and Learning/CTL), menurut Nurhadi, dkk. (2004) merupakan suatu konsep belajar dimana guru 
menghadirkan situasi dunia nyata ke dalam kelas dan mendorong siswa membuat hubungan antara pengetahuan yang dimilikinya dengan penerapannya dalam kehidupan mereka sebagai anggota keluarga dan masyarakat. Proses pembelajaran akan berlangsung lebih alamiah dalam bentuk kegiatan siswa bekerja dan mengalami, bukan transfer pengetahuana dari guru. Dengan konsep ini, hasil pembelajaran diharapkan lebih bermakna bagi siswa untuk memecahkan persoalan, berpikir kritis, dan melaksanakan observasi serta menarik kesimpulan dalam kehidupan jangka panjangnya. Dalam konteks itu, siswa perlu mengerti apa makna belajar, apa manfaatnya, dalam status apa mereka, dan bagaimana mencapainya.

Center on Education and Work at the University of Wisconsin Madison (Kunandar, 2007 : 295) mengartikan pembelajaran kontekstual adalah suatu konsepsi belajar mengajar yang membantu guru menghubungkan isi pelajaran dengan situasi dunia nyata dan memotivasi siswa membuat hubungan-hubungan antara pengetahuan dan aplikasinya dalam kehidupan siswa sebagai anggota keluarga, masyarakat, dan pekerja serta meminta ketekunan belajar.

Sedangkan pembelajaran kontekstual atau contextual teaching and learning (CTL) menurut Depdiknas (2007 : 3) dan Nurhadi (dalam Muslich, 2009 : 41), adalah konsep belajar yang membantu guru mengkaitkan antara materi pembelajaran dengan situasi dunia nyata siswa, dan mendorong siswa membuat hubungan antara pengetahuan yang dimilikinya dengan penerapannya dalam kehidupan mereka sehari-hari. Pengetahuan dan keterampilan siswa diperoleh dari usaha siswa mengkonstruksi sendiri pengetahuan dan ketempilan baru ketika ia belajar, dengan melibatkan tujuh komponen utama pembelajaran yakni : kontruktivisme (constructivism), bertanya (questioning), menyelidiki (inquiry), masyaraka belajar (learning community), pemodelan (modeling), refleksi (reflection), dan penilaian autentik (authentic assessment).

Kenyataan yang ada di lapangan, guru menggunakan pembelajaran konvensional (ceramah). Siswa hanya mendengar dan mencatat. Alasan klasik mengapa guru menggunakan pembelajaran konvensional adalah : terbenturnya oleh waktu tatap muka di kelas, kesulitan untuk menyusun bahan pelajaran yang menggunakan pendekatan yang menarik, sarana dan prasarana yang kurang mendukung. Alasan tersebut menjadikan guru lebih memilih metode ceramah daripada metode lain.

Pembinaan kemampuan guru dalam penerapan pembelajaran kontekstual sejauh ini secara kuantitas sudah cukup memadai. Ada sejumlah teknik pelatihan yang dikemukakan oleh para ahli sesuai dengan sudut pandang dan latar belakang keilmuan mereka, yang salah satunya adalah melalui teknik Focus Group Discussion.

Focus Group Discussion secara sederhana dapat didefinisikan sebagai suatu diskusi yang dilakukan secara sistematis dan terarah mengenai suatu isu atau masalah tertentu. Irwanto (2006: 1-2) mendefinisikan Focus Group Discussion adalah suatu proses 
pengumpulan data dan informasi yang sistematis mengenai suatu permasalahan tertentu yang sangat spesifik melalui diskusi kelompok. Sesuai namanya, pengertian Focus Group Discussion (FGD) mengandung tiga kata kunci:(a). diskusi (bukan wawancara atau obrolan); (b). kelompok (bukan individual); dan (c). terfokus/terarah (bukan bebas). Artinya, walaupun hakikatnya adalah sebuah diskusi, FGD tidak sama dengan wawancara, rapat, atau obrolan beberapa orang di kafe-kafe. FGD bukan pula sekadar kumpul-kumpul beberapa orang untuk membicarakan suatu hal.

Dari paparan di atas, dapat dirumuskan bahwa yang menjadi masalah dalam penelitian ini adalah: Apakah melalui teknik Focus Group Discussion (FGD) dapat meningkatkan kemampuan guru di SMK Negeri 1 Sirandorung Kabupaten Tapanuli Tengah dalam menerapkan Pembelajaran Kontekstual?

\section{Metode Penelitian}

Penelitian ini menggunakan desain penelitian tindakan sekolah (School Action Research). Penelitian ini difokuskan pada penyempurnaan kegiatan pembelajaran dengan penerapan pendekatan pembelajaran kontekstual atau CTL melalui Focus Group Discussion (FGD).

Dilaksanakan pada Guru di SMKN 1 Sirandorung Kabupaten Tapanuli Tengah sebanyak 6 orang yang dilaksanakan pada bulan Mei 2017. Dengan dua siklus masingmasing siklus dengan tahapan, perencanaan, pelaksanaan, observasi dan refleksi.
Teknik analisis data penelitian ini menggunakan jenis statistik deskriptif penskoran yang kemudian dipersentase. Kriteria atau ukuran yang digunakan ialah menentukan nilai (prosentase) yang diklasifikasikan atas dasar tingkatan sebagai berikut (Depdikbud, 1994), yaitu skor 5 (81100) artinya baik sekali, skor 4 (61-80 \%) artinya baik, skor 3 (41-60 \%) artinya cukup, skor 2 (21-40 \%) artinya kurang, dan skor 1 (1-20 \%) artinya kurang sekali.

Indikator keberhasilan penelitian ini ditandai dengan adanya peningkatan kemampuan guru dalam penerapan pembelajaran kontekstual dan perolehan presentasi guru yang mampu menerapkan pembelajaran kontekstual dari hasil observasi saat mikro teaching mencapai 80 $\%$.

\section{Pembahasan dan Hasil}

Kegiatan yang dilaksanakan pada siklus ini adalah peneliti melakukan diskusi dengan guru mata pelajaran disertai dengan memberi contoh-contoh tahapan peleksanaan pembelajaran kontekstual. Selanjutnya guru melaksanakan tahapan yang disarankan oleh peneliti, yaitu merencanakan tindakan pembelajaran dengan menggunakan model pembelajaran CTL. Dalam forum FGD yang sifatnya micro teaching. Secara bergiliran 6 orang guru mempraktekkan pembelajaran kontekstual. Sedangkan peneliti bertindak sebagai observer. Hasil pengamatan dari pelaksanaan ini, sebagaimana terdapat dalam tabel di bawah ini, yaitu:

Tabel 1. Data Kemampuan Guru dalam Menerapkan Pembelajaran Kontekstual Melalui FGD pada siklus I dan II 


\begin{tabular}{|c|c|c|c|}
\hline \multirow{2}{*}{ No } & \multirow{2}{*}{$\begin{array}{c}\text { Jenis Kemampuan } \\
\text { Guru }\end{array}$} & \multicolumn{2}{|c|}{ Rara-Rata Skor } \\
\hline & & Siklus I & Siklus II \\
\hline 1 & $\begin{array}{l}\text { Melakukan Kontruksi } \\
\text { dalam pembelajaran }\end{array}$ & 2,66 & 4,50 \\
\hline 2 & $\begin{array}{l}\text { Melakukan Inkuiri } \\
\text { dalam Pembelajaran }\end{array}$ & 2,50 & 4,00 \\
\hline 3 & $\begin{array}{l}\text { Adanya Questioning } \\
\text { dalam } \\
\text { pembelajaran }\end{array}$ & 3,33 & 4,67 \\
\hline 4 & $\begin{array}{l}\text { Adanya Learning } \\
\text { Community atau belajar } \\
\text { kelompok dalam } \\
\text { pembelajaran }\end{array}$ & 3,17 & 4,33 \\
\hline 5 & $\begin{array}{l}\text { Adanya Modelling } \\
\text { dalam pembelajaran }\end{array}$ & 3,00 & 4,67 \\
\hline 6 & $\begin{array}{l}\text { Dilakukan Refleksi di } \\
\text { akhir pembelajaran }\end{array}$ & 2,83 & 4,50 \\
\hline 7 & $\begin{array}{l}\text { Adanya Authentic } \\
\text { Assesment dalam proses } \\
\text { dan akhir pembelajaran }\end{array}$ & 3,50 & 4,83 \\
\hline & Rata-rata & 2,99 & 4,50 \\
\hline
\end{tabular}

Keterangan:

1 = Sangat Kurang, 2 = Kurang, 3 = Cukup, 4 = Baik, 5 = Sangat Baik

Dari tabel 1 di atas, dapat kita lihat bahwa kemampuan para guru 6 orang di SMK Negeri 1 sirandorung dalam menerapkan pembelajaran kontekstual pada siklus I masih belum sesuai harapan yaitu dengan rata-rata 2,99 atau katagori 'kurang' . Jenis kemampuan yang paling rendah adalah melakukan inkuiri dalam pembelajaran, dengan rata-rata 2,50 (kurang) . Sedangkan jenis kemampuan yang paling menonjol adalah Adanya Authentic Assesment dalam proses dan akhir pembelajaran dengan skor 3,50. Dapat kita lihat bahwa pada siklus I yang berkemampuan sangat baik $0 \%$, baik 14,26 \%, cukup 52,38 \%, kurang 33,26 \%, dan sangat kurang 0,0 \%. Dapat dikatakan yang bernilai di atas baik 14,26\%.
Berdasarkan hasil penelitian pada siklus I ini, menunjukkan bahwa kemampuan guru dalam pembelajaran kontekstual diperlukan usaha perbaikan pada siklus II.

Tindakan pada siklus II dilakukan berdasarkan dari kegiatan tindakan pada siklus I adalah : peneliti perlu memberikan penjelasan lebih detail tentang beberapa kecakapan dalam pembelajaran kontekstual, yaitu: mulai dari kemampuan berfikir konstruktif, berlatih inkuiri (menemukan), berlatih belajar berkelompok (learning community), modeling (pemodelan), melakukan refleksi di akhir pembelajaran, dan melakukan authentic assessment (penilaian yang sebenarnya), karena hal ini mempengaruhi tingkat keberhasilan pembelajaran ini.

pada siklus II sudah ada peningkatan yang cukup signifikan, yaitu dengan ratarata 4,50 atau katagori 'baik', dan sudah tercapai target kemampuan guru dalam menerapkan pembelajaran kontekstual. Jenis kemampuan yang paling rendah adalah masih tetap namun sudah ada peningkatan yang cukup berarti jika dibanding dengan siklus I yaitu melakukan inkuiri dalam pembelajaran, dengan rata-rata pada siklus I sebesar 2,50 (kurang) menjadi 4,00 (baik). Sedangkan jenis kemampuan yang paling menonjol adalah dua kemampuan yaitu Adanya Questioning dalam proses pembelajaran dan Adanya Authentic Assesment dalam proses dan akhir pembelajaran dengan skor masing-masing 4,67 dan 4,83, hal ini juga meningkat jika dibandingkan dengan siklus I dengan skor 3,33 dan 4,50. Disamping itu juga terjadi peningkatan skor di semua jenis kemampuan 
guru jika dibandingkan dengan siklus II. Dapat kita lihat bahwa pada siklus II yang berkemampuan sangat baik 52,38 \%, baik 45,23 \%, cukup 2,39\%, kurang dan sangat kurang 0,00\%. Atau dapat disimpulkan yang diatas baik sebesar 97,61\%. Dengan mendasarkan hasil penelitian pada siklus II ini, menunjukkan bahwa kemampuan guru dalam pembelajaran kontekstual mengalami peningkatan yang cukup signifikan.

Dari hasil penelitian pada siklus II ini, menunjukkan bahwa kemampuan guru dalam pembelajaran kontekstual sudah terjadi peningkatan yang cukup signifikan, dan bahkan melebihi target yang diharapkan dalam penelitian tindakan ini. Dengan demikian penelitian tindakan yang sudah sampai pada siklus II.

\section{Kesimpulan}

Berdasarkan uraian di atas, maka peneliti dapat menyimpulkan bahwa upaya kepala sekolah dalam melakukan teknik FGD kepada guru mampu meningkatkan kemampuan dan ketrampilan guru dalam menerapkan Pembelajaran Kontekstual, dan semakin intensif melakukan FGD bersama para guru mata pelajaran oleh kepala sekolah, semakin meningkatkan kemampuan guru dalam menerapkan pendekatan pembelajaran kontekstual. Karena berdasarkan hasil Penelitian Tindakan telah menunjukkan bahwa teknik FGD yang dilakukan oleh kepala sekolah mampu meningkatkan kemampuan dan ketrampilan guru dalam menerapkan pembelajaran kontekstual, Hal ini dapat dilihat dari hasil penelitian bahwa pada siklus I yang berkemampuan sangat baik $0 \%$, baik 14,26
\%, cukup 52,38 \%, dan kurang 33,26 \%. Pada siklus II yang berkemampuan sangat baik 52,38 \%, baik 45,23 \%, cukup 2,39 \%, kurang dan sangat kurang tidak ada.

\section{Saran}

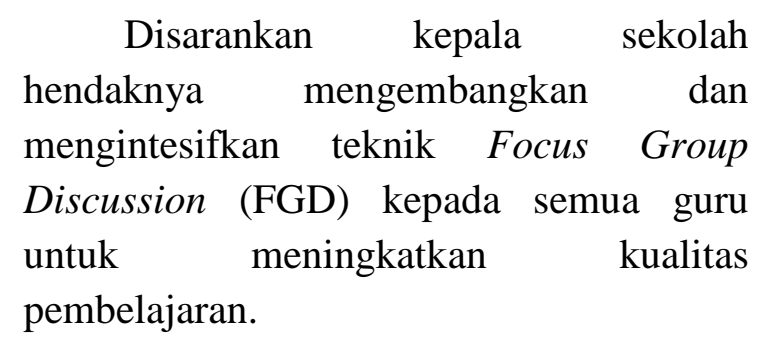

\section{Daftar Pustaka}

Berns, Robert G.and Erickson, Patricia M. (2001). Contextual Teaching and Learning The Highlight

Departemen Pendidikan Nasional (2002), Pendekatan Kontekstual (Contextual Teaching and Learning), Jakarta.

Departemen Pendidikan Nasional. 2007, Petunjuk Teknis Penelitian Tindakan Sekolah, Jakarta.

Irwanto (2006). Focus Group Discussion: A simple manual : Jakarta: Yayasan Obor.

Kardi, S. \& Nur, M. (2000). Pengajaran Langsung. Surabaya : UnesaUniversity Press.

Komalasari, K. (2010). Pembelajaran Kontekstual: Konsep dan Aplikasi. Bandung: Refika Aditama.

Muslich, Masnur. (2011). KTSP : Pembelajaran Berbasis Kompetensi dan Kontekstual. Jakarta. Bumi Aksara. 
Nurhadi. 2003. Pendekatan

Kontekstual. Malang: Universitas Negeri

Malang.

Nurhadi, Burhan Yasin dan Agus

Gerald Senduk (2004). Pembelajaran

Kontekstual dan Penerapannya dalam KBK, Malang : Universitas Negeri Malang 